\title{
PENGARUH DISIPLIN TERHADAP KINERJA PEGAWAI PADA DINAS PEKERJAAN UMUM DAN PENATAAN RUANG KABUPATEN TULANG BAWANG BARAT
}

\author{
Neli Melia Sari ${ }^{(1)}$, Iwan Zulfikar ${ }^{(2)}$, Sodirin ${ }^{(3)}$ \\ Fakultas Ekonomi Universitas Sang Bumi Ruwa Jurai \\ neli.meliasari@gmail.com,iwan.zulfikar@fe.saburai.ac.id,sodirin@fe.saburai.ac.id
}

\begin{abstract}
Abstrak. Disiplin adalah kesadaran dan kesediaan seseorang mentaati semua peraturan organisasi dan norma-norma sosial yang berlaku. Pegawai yang disiplin cenderung memiliki kinerja yang baik. Tujuan penelitian ini adalah ingin mengetahui, Pengaruh disiplin terhadap kinerja pegawai pada Dinas Pekerjaan Umum dan Penataan Ruang Kabupaten Tulang Bawang Barat. Adapun hipotesis dalam penelitian ini adalah terdapat pengaruh disiplin terhadap kinerja pegawai pada Dinas Pekerjaan Umum dan Penataan Ruang Kabupaten Tulang Bawang Barat. Pengumpulan data penelitian menggunakan teknik populasi penelitian dari 40 responden. Metode penelitian yang digunakan adalah analisis kuantitatif yaitu regresi linier sederhana. Berdasarkan hasil analisis diperoleh persamaan bahwa $\mathrm{Y}=29.030+0.263 \mathrm{X}$. Sementara nilai $\mathrm{r}$ Square adalah sebesar 0,133 atau 13,3 persen. Hal ini berarti variabel Disiplin mampu menjelaskan sebesar 13,3\% terhadap variabel Kinerja pegawai dan 86,7 \% dijelaskan oleh variabel lain. Dari persamaan regresi menjelaskan ada pengaruh positif dari Disiplin terhadap Kinerja pegawai yang mana apabila skor Disiplin naik satu skor maka skor Kinerja pegawai akan naik sebesar 0,263 dengan kata lain jika kinerja pegawai naik 0,263 tingkat maka Kinerja pegawai akan naik sebesar 1 tingkat.
\end{abstract}

Kata kunci: Disiplin, Kinerja, Organisasi, Pegawai.

\section{PENDAHULUAN}

Sumber daya manusia yang berkualitas merupakan unsur terpenting bagi semua organisasi atau organisasi, selain dukungan sumber dana, sarana dan prasarana. Hal tersebut sebagaimana diungkapkan oleh Sondang P. Siagian bahwa salah satu bidang fungsional yang bersifat penunjang adalah sumber daya manusia dinyatakan secara katerogikal karena pada analisis terakhir manusia merupakan unsur terpenting yang merupakan unsur yang menentukan berhasil atau tidaknya organisasi untuk mencapai tujuan mengemban misinya (Siagian, 2011). Dengan demikian dijelaskan bahwa manusia merupakan perencana sekaligus pelaku aktif dalam kegiatan organisasi tersebut, oleh karena itu pengembangan sumber daya manusia harus bertahap.
Pada suatu organisasi, yang menjadi perhatian utama adalah bagaimana menciptakan keharmonisan dan keserasian dalam setiap pelaksanaan kegiatan atau aktivitas kerja tersebut. Keharmonisan dan keserasian tersebut dapat tercipta jika sistem kerja dibuat rukun dan kompak sehingga tercipta iklim yang kondusif. Kondisi tersebut pada akhirnya akan membuat para pegawai termotivasi untuk bekerja dengan optimal, sehingga tujuan organisasi dapat terwujud dengan tingkat efisien dan efektivitas yang tinggi.

Pegawai Negeri Sipil (PNS) merupakan salah satu unsur dalam organisasi pemerintah yang memiliki kedudukan sangat strategis dalam rangka mewujudkan tujuan pembangunan nasional. Setiap organisasi pemerintah baik pusat maupun daerah harus memiliki sumber daya manusia pegawai yang memenuhi persyaratan baik secara kuantitas maupun 
kualitas, sehingga dapat melaksanakan tugas dan fungsinya secara professional. Secara umum permasalahan sumber daya manusia pegawai negari sipil itu terletak pada masalah kualitas dan profesionalitas yang akan berpengaruh terhadap kinerja pegawai dalam penyelenggaraan pemerintahan dan pembangunan.

Diantara beberapa aspek yang membuat organisasi dapat mencapai kinerja yang optimal adalah disiplin. Peraturan Pemerintah Nomor 53 Tahun 2015 tentang Disiplin Pegawai Negeri Sipil menggariskan bagaimana PNS berlaku disiplin. Disiplin Pegawai Negeri Sipil adalah kesanggupan Pegawai Negeri Sipil untuk menaati kewajiban dan menghindari larangan yang ditentukan dalam peraturan perundang-undangan dan/atau peraturan kedinasan yang apabila tidak ditaati atau dilanggar dijatuhi hukuman disiplin. Pelanggaran disiplin adalah setiap ucapan, tulisan, atau perbuatan PNS yang tidak menaati kewajiban dan/atau melanggar larangan ketentuan disiplin PNS, baik yang dilakukan di dalam maupun di luar jam kerja.

Disiplin adalah kesadaran dan kesediaan seseorang mentaati semua peraturan organisasi dan norma-norma sosial yang berlaku. Kesadaran adalah sikap seserang yang secara sukarela mentaati semua peraturan dan sadar akan tugas dan tanggung jawabnya. Kesediaan adalah suatu sikap, tingkah laku dan perbuatan seseorang yang sesuai dengan peraturan organisasi baik yang tertulis maupun tidak.

Disiplin kerja sering kali dibicarakan dalam kondisi yang timbul bersifat negatif. Disiplin lebih dikaitkan dengan sangsi atau hukuman. Hodges dalam Yuspratiwi (2010) mengatakan bahwa disiplin dapat diartikan sebagai sikap seseorang atau kelompok yang berniat untuk mengikuti aturan-aturan yang telah diterapkan. Dalam kaitannya dengan pekerjaan, pengertian disiplin kerja adalah suatu sikap dan tingkah laku yang menunjukkan ketaatan pegawai terhadap peraturan organisasi.

Berdasarkan pra observasi sebelum melakukan penelitian pada Dinas Pekerjaan Umum dan Penataan Ruang Kabupaten Tulang Bawang Barat, diketahui permasalahan adalah mulai pelaksanaan tugas kantor tidak tepat waktu (kesiangan), kedisiplinan dalam bekerja kurang optimal, permasalahan terkait kinerja antara lain kinerja pegawai yang masih belum optimal, hal ini diindikasikan dengan tidak tercapainya target kerja yang telah dibebankan kepada pegawai tersebut.

Berdasarkan faktor dan uraian di atas, maka penulis tertarik untuk menelitinya lebih lanjut dengan judul: "Pengaruh Disiplin Terhadap Kinerja Pegawai pada Dinas Pekerjaan Umum dan Penataan Ruang Kabupaten Tulang Bawang Barat".

\section{KAJIAN TEORI}

\section{Pengertian Disiplin}

Disiplin adalah kesadaran dan kesediaan seseorang menanti semua peraturan organisasi dan norma-norma sosial yang berlaku. Kesadaran adalah sikap seserang yang secara sukarela menaati semua peraturan dan sadar akan tugas dan tanggung jawabnya. Kesediaan adalah suatu sikap, tingkah laku dan perbuatan seseorang yang sesuai dengan peraturan organisasi baik yang tertulis maupun tidak. Disiplin kerja dibicarakan dalam kondisi yang sering kali timbul bersifat negatif. Disiplin lebih dikaitkan dengan sangsi atau hukuman. Hodges dalam Yuspratiwi (2010) mengatakan bahwa disiplin dapat diartikan sebagai sikap seseorang atau kelompok yang berniat untuk mengikuti aturan-aturan yang telah diterapkan. Dalam kaitannya dengan pekerjaan, pengertian disiplin kerja adalah suatu sikap dan tingkah laku yang 
menunjukkan ketaatan pegawai terhadap peraturan organisasi.

Niat untuk mentaati peraturan menurut Suryohadiprojo (2017) merupakan suatu kesadaran bahwa tanpa disadari unsur ketaatan, tujuan organisasi tidak akan tercapai. Hal itu berarti bahwa sikap dan perilaku didorong adanya kontrol diri yang kuat. Artinya, sikap dan perilaku untuk mentaati peraturan organisasi muncul dari dalam dirinya. Niat juga dapat diartikan sebagai keinginan untuk berbuat sesuatu atau kemauan untuk menyesuaikan diri dengan aturan-aturan. Sikap dan perilaku dalam disiplin kerja ditandai oleh berbagai inisiatif, dan kehendak untuk mentaati peraturan. Artinya, orang yang dikatakan mempunyai disiplin yang tinggi tidak semata-mata patuh dan taat terhadap peraturan secara kaku dan mati, tetapi juga mempunyai kehendak (niat) untuk menyesuaikan diri dengan peraturanperaturan organisasi.

\section{Indikator-Indikator Disiplin}

Berdasarkan pengertian disiplin dapat ditarik indikator-indikator disiplin kerja sebagai berikut :

1. Disiplin kerja tidak semata-mata patuh dan taat terhadap penggunaan jam kerja saja, misalnya datang dan pulang sesuai jadwal, tidak mangkir jika bekerja, dan tidak mencuri-curi waktu

2. Upaya dalam mentaati peraturan tidak didasarkan adanya perasaan takut, atau terpaksa

3. Komitmen dan loyal pada organisasi yaitu tercermin dari berbagai sikap dalam bekerja

\section{Pengertian Kinerja}

Kinerja pada dasarnya adalah apa yang dilakukan atau tidak dilakukan pegawai. Kinerja pegawai adalah yang mempengaruhi seberapa banyak mereka memberi kontribusi kepada organisasi. Perbaikan kinerja baik untuk individu maupun kelompok menjadi pusat perhatian dalam upaya meningkatkan kinerja organisasi (Mathis dan Jackson, 2012).

Menurut Maier (As'ad, 2011) sebagai kesuksesan seseorang di dalam melaksanakan suatu pekerjaan. Lebih tegas lagi Lawler dan Poter menyatakan bahwa kinerja adalah "succesfull role achievement" yang diperoleh seseorang dari perbuatan-perbuatannya (As'ad, 2011). Dari batasan tersebut As'ad menyimpulkan bahwa kinerja adalah hasil yang dicapai seseorang menurut ukurang yang berlaku untuk pekerjaan yang bersangkutan.

Menurut Bernadin dan Russel (Reni, 2012) kinerja merupakan catatan perolehan yang dihasilkan dari fungsi suatu pekerjaan tertentu atau kegiatan selama periode tertentu atau kegiatan selama periode waktu tertentu. Pengertian kinerja menurut Bernadin ini identik dengan pengertian Hasibuan (2010) yang menyatakan bahwa kinerja adalah suatu hasil kerja yang dicapai seseorang dalam melaksanakan tugas-tugas yang dibebankan kepadanya yang didasarkan atas kecakapan, pengalaman dan kesungguhan serta waktu.

\section{Pengembangan Kriteria Kinerja}

Gomes (2015) berpendapat bahwa ada 3 klasifikasi penting bagi pengembangan kriteria kinerja yang dapat diukur secara obyektif, yaitu :

1. Relevancy, menunjukkan tingkat kesesuaian antara kriteria dengan tujuan prestasi kerja atau kinerja.

2. Reliability, menunjukkan tingkat kriteria yang menghasilkan hasil yang konsisten.

3. Discrimination, mengukur tingkat dimana suatu kriteria kinerja dapat memperlihatkan perbedaan-perbedaan dalam tingkat kinerja. 


\section{METODE PENELITIAN}

\section{Objek Penelitian}

Objek Penelitian dalam penelitian ini adalah pegawai Dinas Pekerjaan Umum dan Penataan Ruang Kabupaten Tulang Bawang Barat. Penelitian dilaksanakan pada rentang waktu Juni-Juli 2017.

\section{Metode Penelitian}

Penelitian yang akan dilaksanakan adalah jenis penelitian deskriptif kuantitatif. Jenis penelitian ini adalah penelitian yang bermaksud membuat pemaparan secara sistimatis, faktual, dan akurat mengenai fakta - fakta dan sifat - sifat populasi tertentu. Jenis penelitian yang digunakan dalam penelitian ini adalah penelitian lapangan (field reseach), bersifat kuantitatif dimana penjelasannya bersifat objektif dengan menjelaskan pendekatanpendekatan yang ada.

\section{Metode dan Teknik Pengumpulan Data}

Dalam penelitian ini jenis data yang diperlukan adalah:

a. Data Primer

Pengumpulan data primer dilakukan melalui survey ke lapangan secara langsung yang disertai dengan wawancara secara terbuka yang dilakukan dengan pegawai Kantor Dinas Pekerjaan Umum dan Penataan Ruang Kabupaten Tulang Bawang Barat.

\section{b. Data Sekunder}

Mencatat data-data yang dipublikasikan Kantor Dinas Pekerjaan Umum dan Penataan Ruang Kabupaten Tulang Bawang Barat dalam bentuk aplikasi dilapangan yang sifatnya berkala (time series). Untuk mendapatkan dan mengumpulkan data yang sesuai dengan kebutuhan dalam penelitian ini maka teknik-teknik yang digunakan adalah sebagai berikut:

\section{Observasi}

yaitu pengamatan langsung guna menguji kebenaran hasil wawancara yang telah dilakukan sebelumnya hingga diperoleh bukti dan fakta empiris dari kantor tersebut.

2. Wawancara

dilakukan dengan cara bertemu langsung dan bertanya secara langsung dengan pegawai Kantor Dinas Pekerjaan Umum dan Penataan Ruang Kabupaten Tulang Bawang Barat.

\section{Kuisioner}

yaitu melakukan penyebaran daftar pernyataan yang diajukan kepada pegawai Kantor Dinas Pekerjaan Umum dan Penataan Ruang Kabupaten Tulang Bawang Barat.

\section{Telaah Dokumentasi dan Kepustakaan} yaitu suatu teknik pengumpulan data yang dilakukan peneliti dengan cara mengkaji buku-buku bacaan, dokumendokumen, peraturan-peraturan dan ketentuan undang-undang serta kebijaksanaan-kebijaksanaan yang berkaitan dengan pokok permasalahan.

\section{Sampel dan Populasi}

Menurut Suharsimi Arikunto (2012) apabila objek penelitian kurang dari 100 maka lebih baik diambil semua, selanjutnya jika jumlah lebih dari 100 maka dapat diambil antara $10-15$ persen . Diketahui jumlah karyawan berjumlah 40 orang, sehingga responden dalam penelitian ini berjumlah 40 orang.

Kriteria Umum untuk skor yang dipergunakan daftar pertanyaan dalam penelitian ini adalah skala likert dengan skoring bernila 1,2,3,4,5 untuk jawaban pada setiap item pertanyaan. 


\section{Analisis Kuantitatif}

Analisis kuantitatif yang dilakukan berdasarkan data primer yang diperoleh dari penyebaran instrument (daftar pertanyaan) kepada sampel, dan untuk mengetahui pengaruh dari variabel bebas (independent variable) terhadap variabel terikat (dependent variable).

Rumus yang digunakan untuk mengukur sejauh mana pengaruh disiplin terhadap kinerja pegawai Kantor Dinas Pekerjaan Umum dan Penataan Ruang Kabupaten Tulang Bawang Barat dengan persamaan regresi linear berganda dengan rumus sebagai berikut :

Persamaan Regresi Linear Sederhana menentukan persamaan regresi linear sederhana untuk X :

$$
Y=a+b X+e
$$

Keterangan:

$$
\begin{aligned}
& \mathrm{Y}=\text { Kinerja } \\
& \mathrm{a}=\text { Konstanta } \\
& \mathrm{b}=\text { Koefisien regresi } \mathrm{X} \\
& \mathrm{X}=\text { Disiplin } \\
& \mathrm{e}=\text { Faktor kesalahan }
\end{aligned}
$$

Untuk mengetahui besarnya pengaruh, penghitungan koefisien korelasi tersebut kemudian dilanjutkan dengan Rumus Koefisien Determinasi atau Koefisien Penentu (KP):

$$
K P=(r)^{2} x 100 \%
$$

Untuk menguji secara hipotesis secara parsial digunakan Uji t dengan rumus :

$$
t_{\text {hitung }}=\frac{r \sqrt{N-2}}{\sqrt{1-r^{2}}}
$$

Keterangan:

$$
\mathrm{t}_{\text {hitung }} \quad=\text { Nilai } \mathrm{t}
$$

$$
\begin{array}{ll}
\mathrm{r} & =\text { Koefisien Korelasi } \\
\mathrm{N} & \text { Jumlah responden } \\
& \quad \text { (Sugiyono, 2008). }
\end{array}
$$

Kriteria untuk Uji $\mathrm{t}$ adalah sebagai berikut :

a) Jika $t_{\text {hitung }}>t_{\text {tabel }}$ maka Ha diterima dan Ho ditolak.

b) Jika $t_{\text {hitung }} \leq \mathrm{t}_{\text {tabel }}$ maka Ha ditolak dan Ho diterima.

Taraf signifikan dalam penelitian ini digunakan $\alpha=0,05$ atau 5\%. Yang dimaksud dengan Hipotesis nol (Ho) dan Hipotesis alternatif $(\mathrm{Ha})$ adalah :

Ho $=r \leq 0=$ Berarti tidak ada pengaruh disiplin terhadap kinerja

$\mathrm{Ha}=\mathrm{r}>0=$ Berarti ada pengaruh disiplin terhadap kinerja.

\section{HASIL DAN PEMBAHASAN}

\section{Uji Validitas Data}

Pengujian validitas butir pertanyaan dilakukan dengan menggunakan koefisien nilai korelasi product moment dengan tingkat kepercayaan 95\%. Berdasarkan uji validitas yang dilakukan, memperlihatkan keseluruhan butir pertanyaan sebagaimana terlampir, dinyatakan valid, sehingga dapat dipergunakan sebagai instrumen dalam penelitian selanjutnya.

\section{Uji Reliabilitas Data}

Pengujian reliabilitas dilakukan bersamaan dengan pengujian validitas untuk mengetahui daftar pertanyaan yang diajukan kepada responden apakah reliabel atau tidak.Dengan menggunakan rumus Alpha Cronbach dengan tingkat kepercayaan $95 \%$ memperlihatkan nilai $\alpha$ total $\mathrm{X}$ dan $\mathrm{Y}$ terletak antara $0,600-0,799$ yang menunjukkan hubungan antar variabel dengan kategori kuat, dan keseluruhan $\alpha$ butir $<\alpha$ total, maka dapat disimpulkan bahwa 
seluruh butir pertanyaan reliabel dan dapat dipergunakan sebagai instrumen dalam penelitian selanjutnya.

\section{Analisis Kuantitatif}

Hasil dari Uji Hipotesis Disiplin berpengaruh Terhadap Kinerja pegawai didapatkan bahwa disiplin berpengaruh signifikan terhadap kinerja pegawai di Dinas Pekerjaan Umum dan Penataan Ruang Kabupaten Tulang Bawang Barat. Hubungan variabel terikat dan variabel bebas dapat ditulis dalam bentuk persamaan regresinya adalah $\mathrm{Y}=29,030+0,263 \mathrm{X}$. Dari persamaan regresi tersebut menjelaskan ada pengaruh dari Disiplin terhadap Kinerja pegawai yang mana apabila skor Disiplin naik satu skor maka skor Kinerja pegawai akan naik sebesar 0,263 .

Hasil analisis data menunjukkan korelasi (r) antara variabel $\mathrm{X}$ dan $\mathrm{Y}$ adalah sebesar 0,366 Nilai ini memberikan arti bahwa variabel bebas (X), yang digunakan dalam model memiliki tingkat hubungan sebesar 36,6 \% terhadap variabel (Y). Sementara nilai $r$ Square adalah sebesar 0,133 atau 13,3 persen. Hal ini berarti variabel Disiplin mampu menjelaskan sebesar 13,3 \% terhadap variabel Kinerja pegawai dan 86,7 \% dijelaskan oleh variabel lain. Dari persamaan regresi menjelaskan ada pengaruh dari disiplin terhadap kinerja pegawai yang mana apabila skor Disiplin naik satu skor maka skor Kinerja pegawai akan naik sebesar 0,263 dengan kata lain jika kinerja pegawai naik 0,263 tingkat maka kinerja pegawai akan naik sebesar 1 tingkat.

\section{KESIMPULAN DAN SARAN}

\section{Kesimpulan}

Berdasarkan analisis data dan pembahasan dapat disimpulkan bahwa hasil analisis data menunjukkan korelasi (r) antara variabel $\mathrm{X}$ dan $\mathrm{Y}$ adalah sebesar 0,366 Nilai ini memberikan arti bahwa variabel bebas $(\mathrm{X})$, yang digunakan dalam model memiliki tingkat hubungan sebesar $36,6 \%$ terhadap variabel (Y). Sementara nilai r Square adalah sebesar 0,133 atau 13,3 persen. Dari persamaan regresi menjelaskan ada pengaruh dari Disiplin terhadap Kinerja pegawai yang mana apabila skor Disiplin naik satu skor maka skor Kinerja pegawai akan naik sebesar 0,263 dengan kata lain jika kinerja pegawai naik 0,263 tingkat maka kinerja pegawai akan naik sebesar 1 tingkat.

\section{Saran}

Adapun saran yang diajukan peneliti adalah sebagai berikut:

1. Variabel kinerja yang perlu mendapat perhatian adalah indikator yaitu mengenai pegawai memanfaatkan waktu dalam bekerja dengan sebaikbaiknya agar pekerjaan cepat selesai karena indikator ini mendapatkan nilai yang paling rendah. Peningkatan indikator ini dapat dilakukan oleh pimpinan agar dapat memotivasi dan menyemangati pegawai dalam bekerja.

2. Variabel disiplin kerja, yang perlu mendapat perhatian untuk peningkatan disiplin kerja adalah kehadiran pegawai di kantor tepat waktu karena nilai indikator tersebut yang paling rendah. Peningkatan indikator ini dapat dilakukan oleh pimpinan dengan memberikan teguran dan sanksi bagi pegawai yang datang terlambat.

\section{DAFTAR PUSTAKA}

Anton Dajan. 2006. Pengantar Metode Statistika. Jakarta: Jilid III, LP3ES.

Gibson, Ivancevich, Donelly, 1999, Organisasi : Perilaku, Struktur, Proses 
I. (Terjemahan), Nunuk Adiarni. Wursanto. (2003). Manajemen Sumber Daya Jakarta: Binarupa Aksara.

Manusia. Edisi Revisi. Jakarta: PT Bumi Aksara.

Greenberg, J and Baron, R. 2014. Behavior in Organizations. New Jersey: Prentice Hall International, Inc.

Hasibuan, Malayu SP. 2005. Manajemen Sumber Daya Manusia. Edisi Revisi. Jakarta: PT Bumi Aksara.

Mangkunegara, Anwar Prabu. 2005. Evaluasi Kinerja. Bandung: Refika Aditama.

Rivai. 2001. Manajemen Sumber Daya Manusia. Edisi Revisi. Jakarta: PT Bumi Aksara.

Sedarmayanti, 2007, Manajemen Sumber Daya Manusia. Edisi Revisi. Jakarta: Bumi Aksara.

Sihombing, Umberto. 2005. Organisasi Kepemimpinan Perilaku Administrasi. Jakarta: Bumi Aksara.

Soejono. 2007. Manajemen Organisasi. Jakarta: Bumi Aksara.

Stoner dan Walker, 2008. Pengertian Pengorganisasian. Jakarta: Rineka Cipta.

Sudjana. 1996. Teknik Analisis Regresi Dan Korelasi. Bandung: Tarsito.

Sugiyono. 2008. Statistik Untuk Penelitian. Cetakan 4. Bandung: Alfabeta.

Umar, Husein. 2005. Riset Pemasaran dan Perilaku Konsumen. Jakarta: PT. Gramedia dan Jakarta Business Research Center.

Uyanto, S, Stanislaus. 2006. Pedoman Analisis Data dengan SPSS. Edisi Pertama. Cetakan Pertama. Yogyakarta: Graha Ilmu. 